\title{
Food Spectrum, Trophic and Length-Weight Characteristics of Nonindigenous Suckermouth Armored Catfishes Pterygoplichthys spp. (Loricariidae) in Vietnam
}

\author{
I. A. Stolbunov ${ }^{a, *}$, V. A. Gusakov ${ }^{a}$, Tran Duc Dien ${ }^{b, c}$, and Nguyen Thi Hai Thanh ${ }^{b}$ \\ ${ }^{a}$ Papanin Institute for Biology of Inland Waters, Russian Academy of Sciences, \\ Borok, Nekouzskii raion, Yaroslavl oblast, Russia \\ ${ }^{b}$ Graduate University of Science and Technology, 18 Hoang Quoc Viet, Cau Giay, Hanoi City, Vietnam \\ ${ }^{c}$ Coastal Branch, Vietnam-Russia Tropical Center, 30 Nguyen Thien Thuat, Nha Trang, Khanh Hoa, Vietnam \\ *e-mail:sia@ibiw.ru \\ Received December 5, 2020; revised April 19, 2021; accepted April 26, 2021
}

\begin{abstract}
The food spectrum and trophic and length-weight characteristics of an invasive species, South American suckermouth armored catfishes Pterygoplichthys spp. (Loricariidae), from lotic and lentic inland waters of Vietnam have been studied. It is found that the diet of suckermouth armored catfishes consists of plant and animal food, as well as organic detritus. According to the predominant type and pattern of feeding, suckermouth armored catfishes can be classified as detritivore gatherers (janitor). Some specimens of catfish with a high consumption of animal food have been identified. It is noted that invasive suckermouth armored catfishes can be a significant food competitor for aboriginal fish species; detritivores; and, possibly, benthophages in the lotic and lentic inland waters of Vietnam.
\end{abstract}

Keywords: suckermouth armored catfishes, Pterygoplichthys spp., Loricariidae, nutrition, trophic characteristics, length-weight relationship, nonindigenous species, Vietnam

DOI: $10.1134 / \mathrm{S} 1995082921050163$

\section{INTRODUCTION}

A great variety of specialized detritophagous fish, which are an important link in the food web and the energy balance of aquatic ecosystems, inhabit the water bodies and watercourses of tropical latitudes (Lowe-McConnell, 1987). The species of the families Prochilodontidae, Curimatidae, armored catfish (Loricariidae) from South America, and some species of the families Cichlidae and Cyprinidae from Africa and Asia are the most abundant and common representatives of tropical detritophagous fish (LoweMcConnell, 1987).

Loricariid catfish are one of the largest and the most specialized group of the order Siluriformes (Gosline, 1947; Armbruster, 2011), which includes 163 genera and 1187 nominal and 1171 valid species (Eschmeyer, 2020). The native range of loricariids is the Neotropecal realm: lentic and lotic waters of South and Central America (Nelson, 2006; Armbruster, 2011).

Suckermouth armored catfishes are one of the major groups of nonindigenous species posing a serious threat to tropical freshwater ecosystems (Lowe et al., 2004; Liang et al., 2005; Godwin et al., 2016; Stolbunov and Tran Duc Dien, 2019). Suckermouth armored catfishes were first found in Southeast Asia more than 30 years ago (Weber, 1992; Kottelat et al., 1993; Welcomme and Vidthayanom, 2003; Page and Robins, 2006). The first local findings of solitary specimens of suckermouth armored catfishes (Pterygoplichthys spp.) in inland waters of Vietnam were recorded relatively recently: in 2003-2004 in the Mekong River in the southern part of the country (Welcomme and Vidthayanom, 2003; Serov, 2004) and in 2006 in the Red River located in the northern part (Levin et al., 2008). Later, self-sustaining highly abundant populations of loricariids were found in the Dinh River (Zworykin and Budaev, 2013) and in the Ea Kao Reservoir (Stolbunov et al., 2015). Numerous populations of Pterygoplichthys spp. inhabiting the basins of all relatively large rivers of Central and Southern Vietnam were recorded in 2017-2019 (Stolbunov et al., 2017; Gusakov et al., 2018; Stolbunov et al., 2017, 2020, 2021). According to the data of phenetic, morphological, and molecular genetic analyses, it was found that currently two species of suckermouth armored catfish reliably inhabit the water bodies and watercourses of Vietnam: P. pardalis (Castelnau, 1855) and P. disjunctivus (Weber, 1991), and each of them is represented by several phylogenetic lines whose representatives are able to hybridize with each other (Stol- 
Table 1. Length-weight and trophic characteristics of the studied suckermouth armored catfish Pterygoplichthys spp.

\begin{tabular}{l|c|c}
\hline \multicolumn{1}{c|}{ Parameters } & $M \pm S E$ & min-max \\
\hline Total body length, cm & $25 \pm 5$ & $10-41$ \\
Standard body length, cm & $19 \pm 4$ & $8-31$ \\
Body weight, g & $148 \pm 8$ & $11-408$ \\
Weight of the bolus, g & $5.24 \pm 0.94$ & $0.04-34.35$ \\
Length of gastrointestinal tract, cm & $277 \pm 17$ & $112-606$ \\
\hline
\end{tabular}

$M \pm S E$ is the mean and its standard error; $\min -\max$ is minimum and maximum values.

bunov et al., 2021). Their high adaptive potential and fecundity (Armbruster, 1998; Nico and Fuller, 1999; Mendoza et al., 2009; Rueda-Jasso et al., 2013) allow them to quickly colonize spatial and trophic niches in new habitats, replacing native fish species (Chaichana et al., 2011; Orfinger and Goodding, 2018; Stolbunov and Tran Duc Dien, 2019).

Suckermouth armored catfish are characterized by the presence of a ventral oral disk and jaws specialized for surface attachment to submerged objects and different substrates and benthic feeding (Power, 1984a, 1984b; Schaefer, 1988). The trophic specialization of loricariids is determined by the morphological diversification of the structure of the oral and maxillary apparatus, feeding habits, and digestive processes of fish (Gerking, 1994; Lujan, 2009; Lujan, Armbruster, 2012). A number of studies have been devoted to the functional morphology, trophic specialization, and feeding behavior of loricariids (Angelescu and Gneri, 1949; Power, 1983; Py-Daniel, 1984; Schaefer and Lauder, 1986, 1996; Fugi, 1993; Buck, 1994; Buck and Sazima, 1995; Fugi et al., 1996; Armbruster, 1998; Lujan, 2009; Lujan and Armbruster, 2012). Loricariids feed by scraping organic detritus, periphyton, remains of higher plants (including woody debris by some species), and aquatic invertebrates (mainly benthic ones) (Arcifa, and Meschiatti, 1993; Castro et al., 2003; Chaichana et al., 2011; Lujan et al., 2011, 2012 etc.). Suckermouth armored catfish may also feed on eggs and juveniles of other fish species (Cook-Hildreth, 2009; Chaichana and Jongphadungkiet, 2012; Chaichana et al., 2013). The relationship between the morphological similarity and the similarity of the diet of sympatric loricariid species indicates the importance of feeding specialization in the fish trophic niche segregation (Delariva and Agostinho, 2001). In some cases, armored catfishes manifested clearly expressed agonistic and territorial behavior in relation to other fish species aimed at obtaining preferential access to the most energetically valuable food resources: benthic compared to plant detritus (Lujan et al., 2012).

It has been currently established that suckermouth armored catfishes Pterygoplichthys spp. inhabit the basins of practically all large river systems of Vietnam at different altitudes above sea level, from lowlands to mountain regions: Mekong, Dong Nai, Serepok, Da Rang, Cai, and many others (Gusakov et al., 2018; Stolbunov and Tran Duc Dien, 2019; Stolbunov et al., 2017, 2020, 2021). Apparently there are close competitive interactions, including for food resources, between numerous populations of armored catfish and native fish species. Accordingly, a number of questions arise: what sources play the main role in the diet of the invaders (loricariids) in new habitats and how can this affect the native species of the fish population in water bodies of Vietnam?

The aim of this study is to analyze the food spectrum of suckermouth armored catfish in lentic and lotic waters of Vietnam.

\section{MATERIALS AND METHODS}

Ichthyological material was collected in DecembeFebruary $2016-2017$ in the Ea Kao $\left(12^{\circ} 36.554^{\prime} \mathrm{N}\right.$, $108^{\circ} 2.439^{\prime}$ E) and Suoi Trau $\left(12^{\circ} 30.302^{\prime} \mathrm{N}\right.$, $\left.109^{\circ} 2.694^{\prime} \mathrm{E}\right)$ reservoirs, the Dinh River $\left(12^{\circ} 29.740^{\prime}\right.$ $\left.\mathrm{N}, 109^{\circ} 7.686^{\prime} \mathrm{E}\right)$, and the Serepok $\left(12^{\circ} 49.000^{\prime} \mathrm{N}\right.$, $\left.107^{\circ} 51.045^{\prime} \mathrm{E}\right)$ and Am Chua channels $\left(12^{\circ} 17.436^{\prime} \mathrm{N}\right.$, $\left.109^{\circ} 6.063^{\prime} \mathrm{E}\right)$. Fish were caught using fixed gill nets (22-40 mm mesh size) and a frame lift net (Kinalev's net).

The total body length, standard body length, and the length of the gastrointestinal tracts of fish were measured. The weight of fish and their food boluses were determined. Fish feeding habits were studied using qualitative and quantitative techniques (Metodicheskoe ..., 1974). The recovered weight of food organisms was obtained using the equation of the lengthweight relationship, tables of standard weights, and nomograms (Mordukhai-Boltovskoi, 1954; Chislenko, 1968; Balushkina and Vinberg, 1979; Kurashov, 2007 etc.). A total of 155 specimens were analyzed according to the length-weight characteristics and 40 fish specimens according to trophic ones.

\section{RESULTS}

The length-weight and trophic characteristics of the studied suckermouth armored catfishes are given in Table 1. Fish caught during the period under study were characterized by a negative allometric growth (Mina and Klevezel, 1976) (Fig. 1). The linear growth of loricariids prevailed over the growth in weight of fish and this was manifested to a greater degree in fish under lotic conditions (Fig. 1a) than in lentic ones (Fig. 1b).

The length of the gastrointestinal tract of the studied armored catfishes of different sizes varied widely (Table 1) and exceeded the total length of fish 1217 times. A significant linear relationship was found between the total body length and the length of the gastrointestinal tract of fish (Fig. 2). 
The food spectrum of suckermouth armored catfish included mineral, plant, and animal ingredients (Table 2). The main mineral and plant components of the food bolus were mostly represented by small fractions of bottom sediments (clay, pelitic, and powdery sands), microscopic and larger detritus particles of uncertain origin, and plant remains. The weight of the food bolus of the studied specimens of suckermouth armored catfish varied widely from $0.04 \mathrm{~g}$ to $34.35 \mathrm{~g}$ (on average $\sim 5 \mathrm{~g}$ ) (Table 1 ).

Sediments and fine various detrital particles prevailed in the diet of most studied specimens. However, a high content of relatively large $(>5 \mathrm{~mm})$ remains of higher semiaquatic and aquatic vegetation, as well as medium and large fractions of sand, which constituted $1-3 \%$ of the total mass of the fish food bolus, was found in the food bolus of some fish.

The content of animal food in the digestive tract of armored catfishes was relatively low. Benthic, planktonic, and amphibiotic groups of organisms were found (Fig. 3).

A suckermouth armored catfish (Dinh River) was found in which amphibiotic organisms constituted the main portion of animal food in terms of abundance and biomass, unlike other fish. The food bolus of this specimen contained 620 amphibiotic larvae of biting midges (in other fish, it was 0-26 specimens) and 212 larvae of flies from the family Dolichopodidae (0-5 specimens in other fish). Terrestrial mites, ants, and other terrestrial insects were also found (Table 2).

The total biomass of animal food components of suckermouth armored catfishes was on average $\sim 0.1 \%$ of the total weight of the fish food (in some specimens, 0.3-1.0\%). Nematodes, cladocerans of the genus Bosminopsis, cyclopoids, and ostracods Cypria cf. furfuracea and chironomid larvae prevailed in respect to the frequency of occurrence in the animal food of suckermouth armored catfishes. Copepods and the ostracod $C$. cf. furfuracea prevailed in the bolus in terms of abundance (Table 2). The average size of invertebrates in fish diet did not exceed 3-5 mm.

\section{DISCUSSION}

The results of a study into the food spectrum of suckermouth armored catfishes have shown that most food organisms detected in the boluses of fish are typical representatives of hydrofauna of water bodies in Vietnam (Gusakov et al., 2014; Ekologia ..., 2014). The frequency of occurrence of hydrobionts detected in the food of loricarids is obviously determined by their availability, prevalence, and abundance.

The analysis of the relative role of different ecological groups of animal origin in the food spectrum of suckermouth armored catfish has showed that they are mainly represented by benthic and planktonic invertebrates. Amphibiotic and terrestrial organisms were also found in the diet of loricariids. Similar feeding
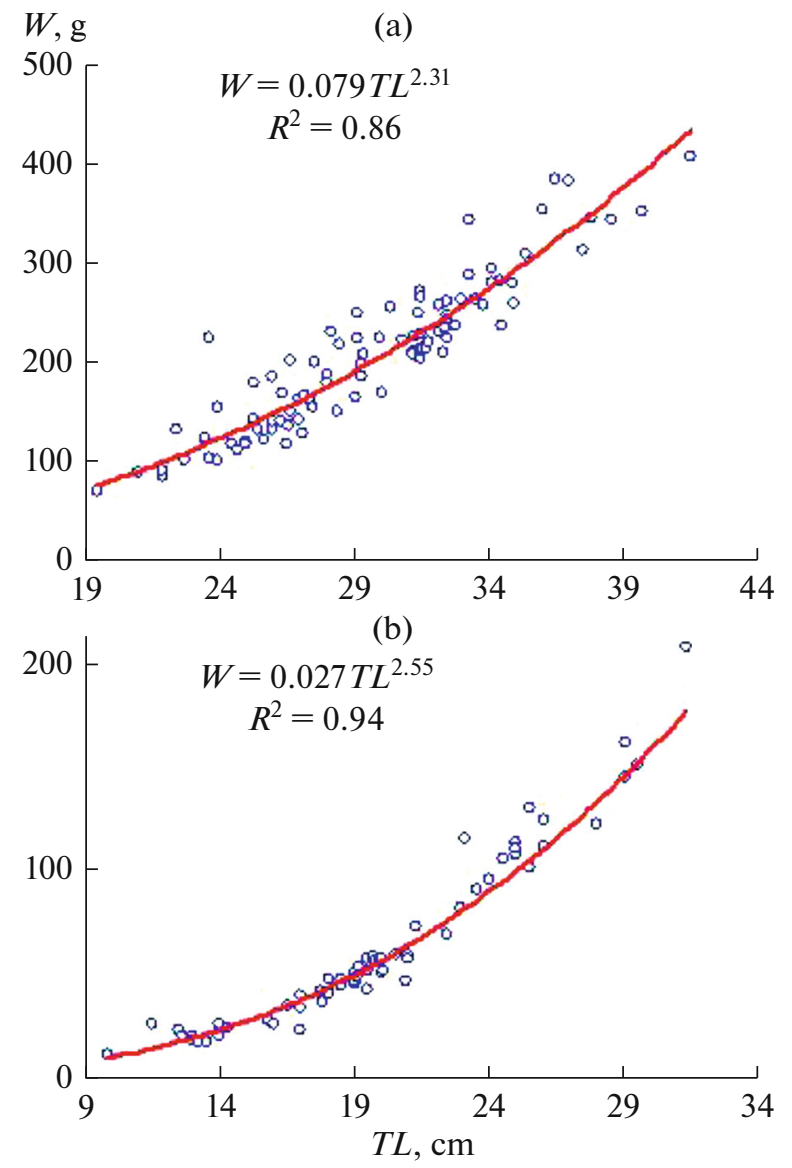

Fig. 1. Length-weight relationship of suckermouth armored catfishes in different habitats; (a) lotic conditions $(n=92$ ind.): Dinh River, Serepok channel, and Am Chua channel; (b) lentic conditions ( $n=63$ ind.): Suoi Trau Reservoir and Ea Kao Reservoir. $T L$, total body length and $W$, body weight.

patterns and food composition were previously observed in other detritophagous fish that swallow the sediments together with its inhabitants, the Nile Oreochromis niloticus (L.) and the Mozambique O. mossambicus (Peters) tilapia, in different water bodies in Vietnam (Stolbunov et al., 2015; Stolbunov and Gusakov, 2015).

It should be mentioned that the studies were conducted during the rainy season, when all water bodies and watercourses were overflowed and, as a result, large coastal areas of the land were flooded. The presence of a significant number of amphibiotic and terrestrial animals in the catfish diet is explained by the fact that some of the studied fish obviously foraged on flooded territories, where invertebrates living on land and in moist coastal soils were consumed together with sediments and detritus. Thus, a specimen of suckermouth armored catfish was found in the Dinh River, in which $\sim 95 \%$ of its animal food was composed of amphibiontic organisms (larvae of biting midges and other dipterans) (Table 2). Taking into account 


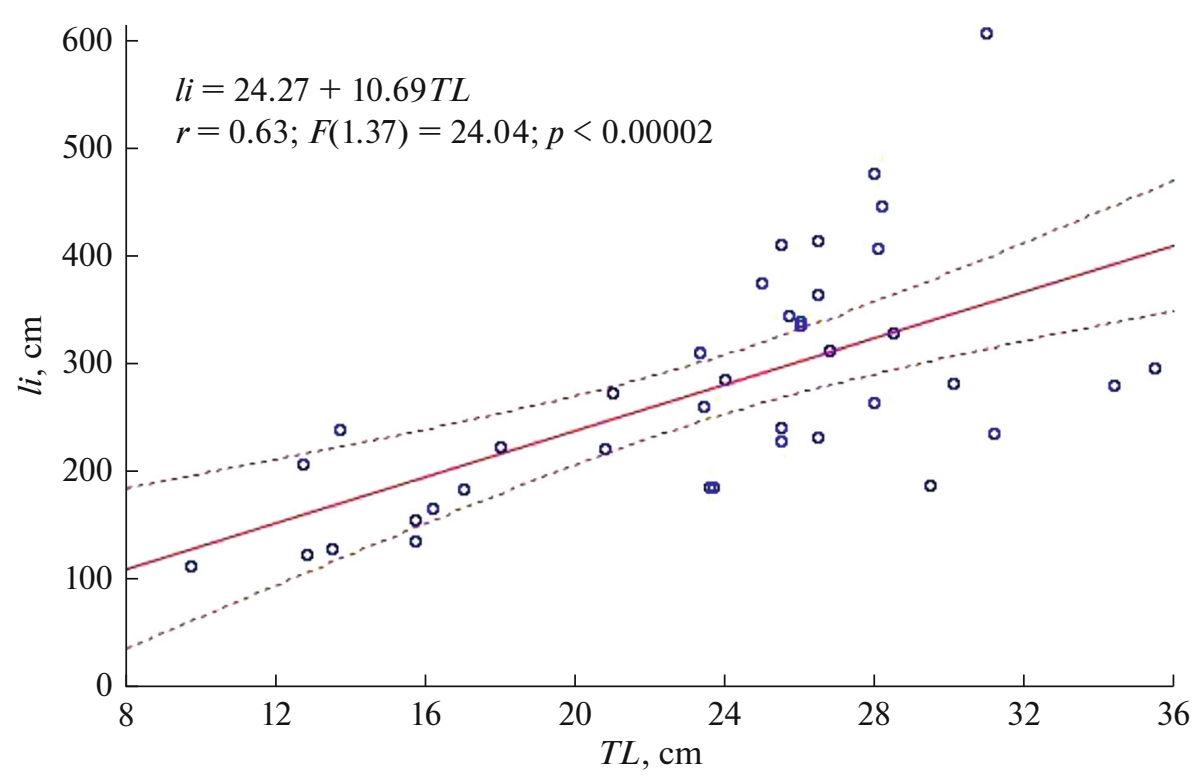

Fig. 2. Regression dependence of the intestinal length $(l i, \mathrm{~cm})$ on the total body length $(T L, \mathrm{~cm})$ of suckermouth armored catfishes. The dotted line indicates a $95 \%$ confidence interval.

the large number and the pattern of location of forage invertebrates in the fish intestine (larvae of amphibiontic insects and ants occurred in groups of several specimens), it may be suggested that this specimen chose "feeding spots" in areas with high concentrations of animals for feeding. Nevertheless, the total recovered weight of its animal food was only $1 \%$ of the mass of the food bolus even with such feeding behavior.

A suckermouth armored catfish was found in the discharge channel of the Serepok Reservoir downstream the dam of the hydroelectric power plant; the predominant component of its animal food was composed of planktonic crustaceans, cyclopoids, Diaptomus species, and cladocerans (species of the genus Bosminopsis and family Sididae etc.) (Table 2). The abundance of Sididae gen. spp. in the intestine of this catfish reached 668 ind., Cyclopoidae gen. spp. 20177 ind., and Diaptomidae gen. spp. 315 ind. Meiobenthic crustaceans (harpacticoids, ostracods) and nematodes were also found in the food. The total recovered weight of animal food of this specimen was $0.6 \%$ of the total weight of the food bolus. The rest of the content of the digestive tract of the fish was composed of bottom sediments (red clay) and fine, mainly plant detritus. It is known that, in some cases, planktonic organisms entering the water intake (culvert) of hydraulic structures can receive injuries and die (Loginov and Gelashvili, 2016). Dead zooplankton organisms settle to the bottom as the current weakens in the zone of discharge (Ekologicheskie ..., 2001; etc.). The considered specimen of suckermouth armored catfish probably preferred to feed in this area for some time after finding a feeding spot that was relatively rich in animal compo- nents. Further studies, including experimental ones, are required to exactly determine individual features of the feeding habits of suckermouth armored catfishes.

\section{CONCLUSIONS}

The first studies on the spectrum and feeding habitats of invasive suckermouth armored catfish (Pterygoplichthys spp.) that have invaded water bodies and watercourses of Vietnam have shown that in new habitats they behave as typical detritophage gatherers, similar to what is observed in their initial range in South and Central America, where they are commonly known as Janitor fish (Lujan et al., 2012; Froese and Pauly, 2012). The analysis of the qualitative and quantitative composition of the food bolus in the studied specimens has showed that the fish feed mainly on silted areas rich in different detritus and plant residues, swallowing bottom sediments together with invertebrates. Some specimens apparently prefer habitats with high concentrations of animal food that is more typical for facultative zoophages. However, based on a low mass fraction of animal food in the boluses of fish and taking into consideration the microscopic sizes of food objects, it is unlikely that zooplankton and benthic organisms are selectively consumed by armored catfishes. Apparently, they should be considered an accompanying food of loricariids. The results indicate that, when a high abundance of the population is achieved, armored catfishes are able to strongly compete for food resources with local detritophagous fish and probably benthophages. 


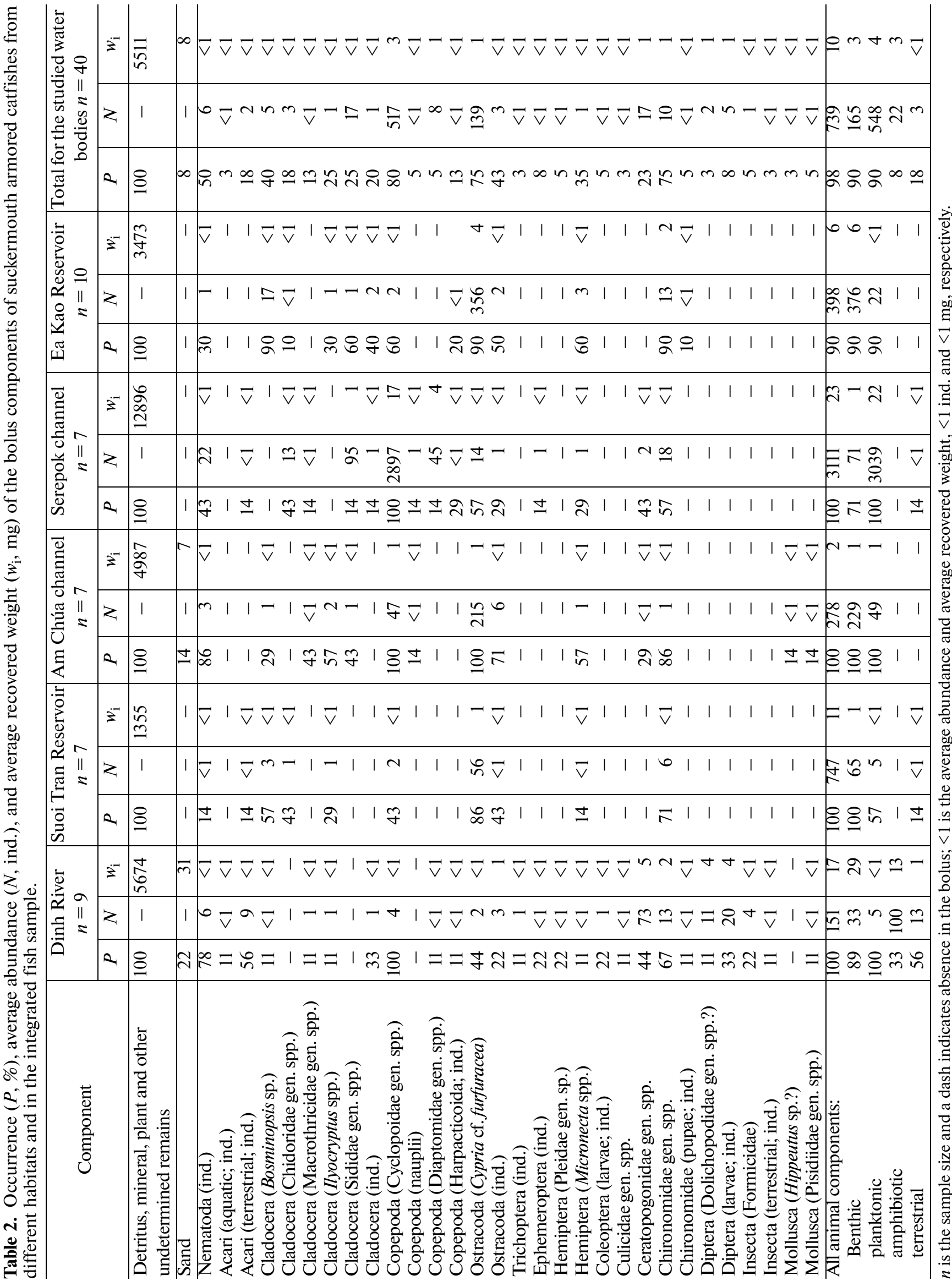


(a)

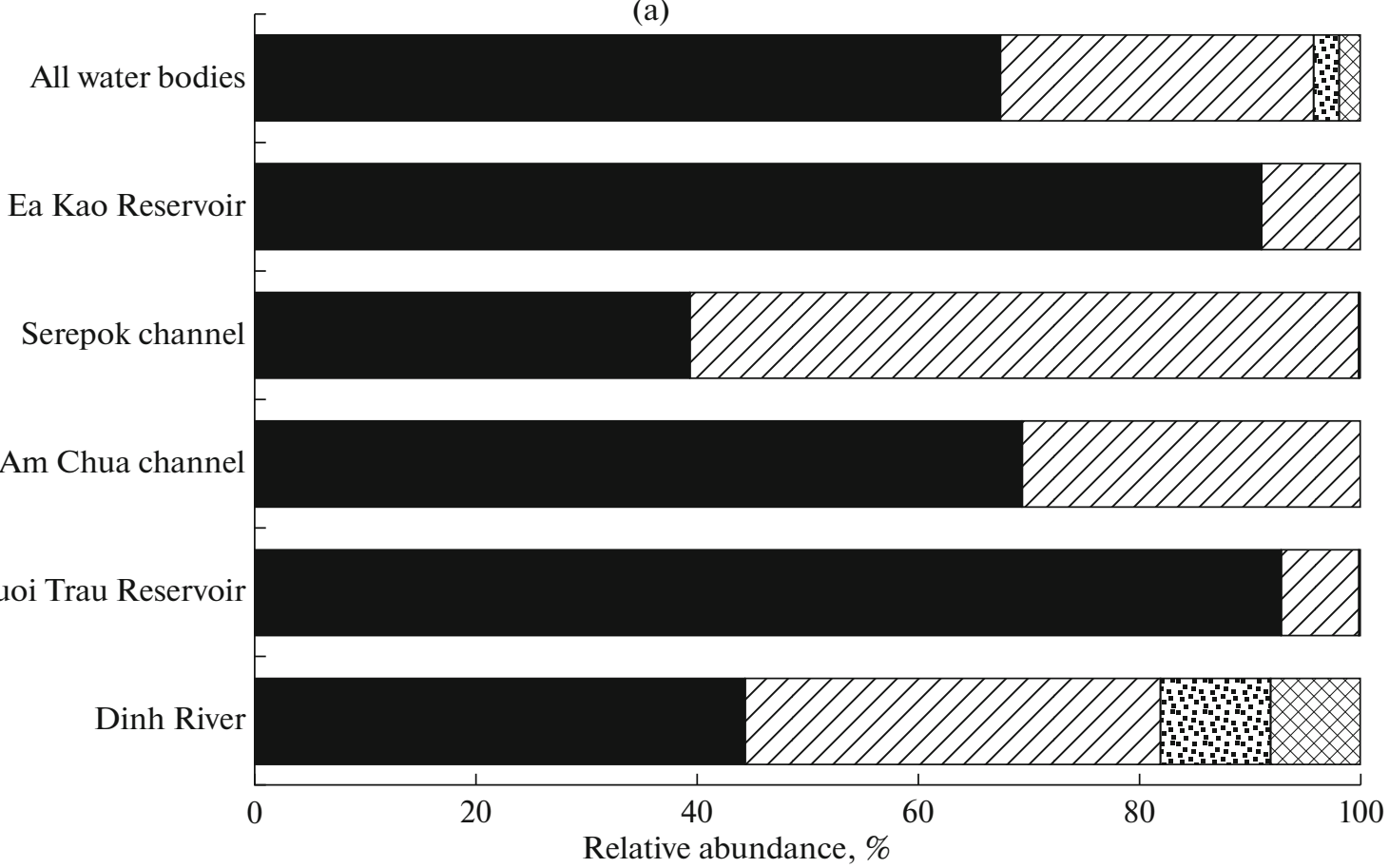

(b)

All water bodies
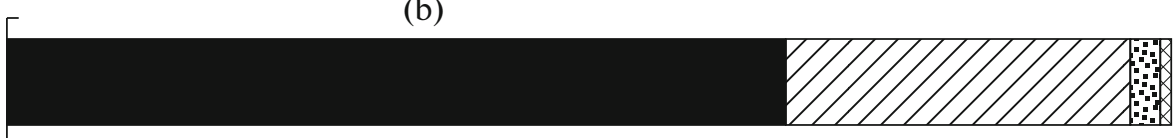

Ea Kao Reservoir

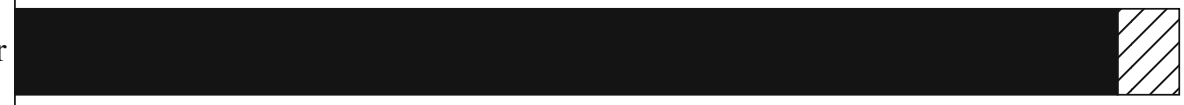

Serepok channel

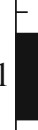

Am Chua channel

$$
-
$$

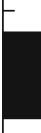

Suoi Trau Reservoir

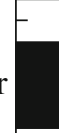

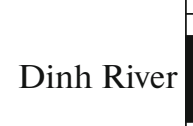

$$
\text { E }
$$

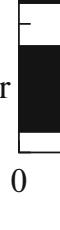

Benthic

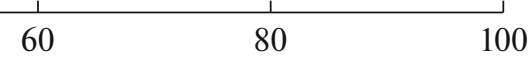

60

Relative biomass, \%

Amphibiontic $⿴$ Terrestrial

Fig. 3. Relative abundance (a) and biomass (b) of different ecological groups of invertebrates in the bolus of suckermouth armored catfishes from different habitats.

\section{ACKNOWLEDGMENTS}

We are very grateful to the administration and technical staff of the Vietnam-Russia Tropical Centre for providing the opportunity to conduct our research and their assis- tance. We are particularly thankful to local fishermen for their help in collecting the material. We sincerely thank D.A. Pavlov (Moscow State University) for valuable advice and recommendations while we prepared the manuscript. 


\section{FUNDING}

This study was performed as part of State Task no. 121051100104-6 and theme Ecolan 3.2 of the VietnamRussia Tropical Centre.

\section{COMPLIANCE WITH ETHICAL STANDARDS}

Conflict of interests. The authors declare that they have no conflicts of interest.

Statement on the welfare of animals. All applicable international, national, and/or institutional guidelines for the care and use of animals were followed.

\section{OPEN ACCESS}

This article is licensed under a Creative Commons Attribution 4.0 International License, which permits use, sharing, adaptation, distribution and reproduction in any medium or format, as long as you give appropriate credit to the original author(s) and the source, provide a link to the Creative Commons license, and indicate if changes were made. The images or other third party material in this article are included in the article's Creative Commons license, unless indicated otherwise in a credit line to the material. If material is not included in the article's Creative Commons license and your intended use is not permitted by statutory regulation or exceeds the permitted use, you will need to obtain permission directly from the copyright holder. To view a copy of this license, visit http://creativecommons.org/licenses/by/4.0/.

\section{REFERENCES}

Angelescu, V. and Gneri, F.S., Adaptaciones del aparato digestivo al re'gimen alimenticio en algunos peces del rio Uruguay y del rio de la Plata, Instituto Nacionale de la Investigacion Ciencias Naturales, 1949, vol. 1, p. 161.

Arcifa, M.S. and Meschiatti, A.J., Distribution and feeding ecology of fishes in a Brazilian reservoir: Lake Monte Alegre, Interciencia, 1993, vol. 18, p. 302.

Armbruster, J.W., Modifications of the digestive tract for holding air in loricariid and scoloplacid catfishes, Copeia, 1998, vol. 3, p. 663.

Armbruster, J.W., Global catfish biodiversity, Am. Fish. Soc. Symp., 2011, vol. 77, p. 15.

Balushkina, E.V. and Vinberg, G.G., The relationship between the length and body weight of planktonic crustaceans, in Eksperimental'nye i polevye issledovaniya biologicheskikh osnov produktivnosti ozer (Experimental and Field Studies of the Biological Foundations of the Productivity of Lakes), Leningrad: Zool. Inst. Akad. Nauk SSSR, 1979, p. 58. Buck, S., Historia natural de uma comunidade de cascudos (Loricariidae) na Mata Atlantica: habitat, atividade e alimentacao, Master's Thesis, Rio Claro: UNESP, Instituto de Biociencia, Universidade Estadual Paulista, 1994.

Buck, S. and Sazima, I., An assemblage of mailed catfishes (Loricariidae) in southeastern Brazil: distribution, activity, and feeding, Ichthyol. Explor. Freshwaters, 1995, vol. 6, p. 325.

Castro, A.L.M., Abrecht, M.P., and Pellegrini-Caramaschi, É., Diet of Hypostomus emarginatus (Teleostei; Lo- ricariidae) in the upper Tocantins river before and after impoundment by the Serra da Mesa Hydroelectric Dam, Biocièncias (Porto Alegre), 2003, vol. 11, p. 23.

Chaichana, R. and Jongphadungkiet, S., Assessment of the invasive catfish Pterygoplichthys pardalis (Castelnau, 1855) in Thailand: ecological impacts and biological control alternatives, Trop. Zool., vol. 25, no. 4, p. 173.

Chaichana, R., Pouangcharean, S., and Ruangvich, Y., Habitat, abundance and diet of invasive suckermouth armored catfish (Loricariidae, Pterygoplichthys) in the Nong Yai Canal, East Thailand, Trop. Zool., 2011, vol. 24, p. 49.

Chaichana, R., Pouangcharean, S., and Yoonphand, R., Foraging effects of the invasive alien fish Pterygoplichthys on eggs and first-feeding fry of the native Clarias macrocephalus in Thailand, Kasetsart J. (Nat. Sci.), 2013, vol. 47, p. 581.

Chislenko, L.L., Nomogrammy dlya opredeleniya vesa vodnykh organizmov po razmeram i forme tela (Nomograms for Determining the Weight of Aquatic Organisms by Body Size and Shape), Leningrad: Nauka, 1968.

Cook-Hildreth, S.L., Exotic Armored Catfishes in Texas: Reproductive Biology and Effects of Foraging on Egg Survival of Native Fishes (Etheostoma fonticola, Endangered and Dionda diaboli, Threatened), San Marcos: Texas State UniversitySan Marcos, 2009.

Delariva, R.L. and Agostinho, A.A., Relationship between morphology and diets of six neotropical loricariids, J. Fish. Biol., vol. 58, p. 832.

https://doi.org/10.1006/jfbi.2000.1499

Ekologicheskie problemy Verkhnei Volgi (Environmental problems of the Upper Volga), Yaroslavl: Yarosl. Gos. Univ., 2001.

Ekologiya vnutrennikh vod V'etnama (Ecology of Inland Waters of Vietnam), Moscow: KMK, 2014.

Eschmeyer, W.N., Catalog of Fishes, California Academy of Sciences, San Francisco, USA, 2020. http://researcharchive.calacademy.org/research/ichthyology/catalog/fishcatmain.asp. Updated May 4, 2020.

Froese, R. and Pauly, D., FishBase, 2012. http://www.fishbase.org, ver. 12/2012.

Fugi, R., Estratégias alimentares utilizadas por cinco espécies de peixes comedoras de fundo do alto rio Parana, Masters Thesis, PR-MS, Sao Carlos: UFSCar, Universidade Federal de Sao Carlos, 1993.

Fugi, R., Hahn, N.S., and Agostinho, A.A., Feeding styles of five species of bottom-feeding fishes of the high Parana River, Environ. Biol. Fishes, 1996, vol. 46, p. 297.

Gerking, S.D., Feeding Ecology of Fish, San Diego: Academic, 1994.

Godwin, J.C., Steen, D.A., Werneke, D., and Armbruster, J.W., Two significant records of exotic tropical freshwater fishes in Southern Alabama, Notes Southeast. Nat., 2016, no. 15/4, p. N57.

Gosline, W.A., Contributions to the classification of the loricariid catfishes, Arq. Mus. Nac. (Rio de Janeiro), 1947, vol. 41, p. 79.

Gusakov, V.A., Gagarin, V.G., and Semenova, L.M., Taxonomic composition and structure of meio- and macrozoobenthos of the investigated water bodies, in Ekologiya vnutrennikh vod V'etnama (Ecology of Inland Waters of Vietnam), Moscow: KMK, 2014, p. 163.

Gusakov, V.A., Stolbunov, I.A., and Tran Duc Dien, Modern distribution of armored catfishes (Siluriformes: Lorica- 
riidae) in Central Vietnam, Inland Water Biol., 2018, vol. 11, no. 2 , p. 179 .

https://doi.org/10.1134/S1995082918020050

Kottelat, M., Whitten, A.J., Kartikasari, S.N., and Wirjoatmodjo, S., Freshwater Fishes of Western Indonesia and Sulawesi, Hong Kong: Periplus Editions, 1993.

Kurashov, E.A., Methods and approaches for the quantitative study of freshwater meiobenthos, in Aktual'nye voprosy izucheniya mikro-, meiozoobentosa i fauny zaroslei presnovodnykh vodoemov (Actual Problems of the Study of Micro-, Meiozoobenthos and Fauna of Thickets of Freshwater Water Bodies), Nizhny Novgorod: Vektor TiS, 2007, p. 5.

Levin, B.A., Phuong, P.H., and Pavlov, D.S., Discovery of the Amazon sailfin catfish Pterygoplichthys pardalis (Castelnau, 1855) (Teleostei: Loricariidae) in Vietnam, J. Appl. Ichthyol., 2008, vol. 24, p. 715.

Liang, S.H., Wu, H.P., and Shieh, B.S., Size structure, reproductive phenology, and sex ratio of an exotic armored catfih (Liposarcus multiradiatus) in the Kaoping River of southern Taiwan, Zool. Stud., 2005, vol. 44, p. 252.

Loginov, V.V. and Gelashvili, D.B., Harm to aquatic biological resources of reservoirs of the Volga-Kama cascade from the impact of hydroelectric power plants, Prints. Ekol., 2016, no. 4, p. 4.

https://doi.org/10.15393/j1.art.2016.4681

Lowe-McConnell, R.H., Ecological Studies in Tropical Fish Communities, New York: Cambridge Univ. Press, 1987.

Lowe, S., Browne, M., Boudjelas, S., and De Poorter, M., 100 of the World's Worst Invasive Alien Species, A Selection from the Global Invasive Species Database, Auckland: Invasive Species Specialist Group (ISSG) of the Species Survival Commission (SSC) of the World Conservation Union (IUCN), 2004.

Lujan, N.K., Jaw morphofunctional diversity, trophic ecology, and historical biogeography of the neotropical suckermouth armored catfishes (Siluriformes, Loricariidae), $A$ Dissertation Submitted to the Graduate Faculty of Auburn University in Partial Fulfillment of the Requirements for the Degree of Doctor of Philosophy, Auburn, Alabama: Auburn University, 2009.

Lujan, N.T. and Armbruster, J.W., Morphological and functional diversity of the mandible in suckermouth armored catfishes (Siluriformes: Loricariidae), J. Morphol., 2012, vol. 273, p. 24.

Lujan, N.K., German, D.P., and Winemiller, K.O., Do wood grazing fishes partition their niche? Morphological and isotopic evidence for trophic segregation in neotropical Loricariidae, Funct. Ecol., 2011, vol. 25, p. 1327.

Lujan, N.K., Winemiller, K.O., and Armbruster, J.W., Trophic diversity in the evolution and community assembly of loricariid catfishes, BMC Evol. Biol., 2012, vol. 12, p. 124.

Mendoza, R.E., Cudmore, B., Orr, R., et al., Trinational Risk Assessment Guidelines for Aquatic Alien Invasive Species, Canada, Montreal: Commission for Environmental Cooperation, 2009.

Metodicheskoe posobie po izucheniyu pitaniya i pishchevykh otnoshenii ryb $v$ estestvennykh usloviyakh (Methodological Guide for the Study of Nutrition and Food Relations of Fishes in Natural Conditions), Moscow: Nauka, 1974.

Mina, M.V. and Klevezal', G.A., Rost zhivotnykh (Animal Growth), Moscow: Nauka, 1976.
Mordukhai-Boltovskoi, F.D., Materials on the average weight of aquatic invertebrates in the Don River basin, Tr. Probl. Temat. Soveshch. Zool. Inst., 1954, no. 2, p. 223.

Nelson, J.S., Fishes of the World, New York: Wiley, 2006.

Nico, L.G. and Fuller, P.L., Spatial and temporal patterns of nonindigenous fish introductions in the United States, Fisheries, 1999, vol. 24, no. 1, p. 16.

Orfinger, A.B. and Goodding, D.G., The global invasion of the suckermouth armored catfish genus Pterygoplichthys (Siluriformes: Loricariidae): annotated list of species, distributional dummary, and assessment of impacts, Zool. Stud., 2018, vol. 57, p. 1.

Page, L.M. and Robins, R.H., Identification of sailfin catfishes (Teleostei: Loricariidae) in southeastern Asia, Raffles Bull. Zool., 2006, vol. 54, p. 455.

Power, M.E., Grazing responses of tropical freshwater fishes to different scales of variation in their food, Environ. Biol. Fishes, 1983, vol. 9, p. 103.

Power, M.E., Depth distributions of armored catfish: predator-induced resource avoidance?, Ecology, 1984a, vol. 65, p. 523.

Power, M.E., The importance of sediment in the grazing ecology and size class interactions of an armored catfish, Ancistrus spinosus, Environ. Biol. Fishes, 1984b, vol. 10, p. 173.

Py-Daniel, L.H.R., Sistematica dos Loricariidae (Ostariophysi, Siluroidei) do complexo de lagos do Janauaca, Amazonas e aspectos da sua biologia e ecologia, Masters Thesis, Manaus: INPA, Instituto Nacional de Pesquisas da Amazonia, 1984.

Rueda-Jasso, R.A., Campos-Mendoza, A., Arreguin-Sanchez, F., et al., The biological and reproductive parameters of the invasive armored catfish Pterygoplichthys disjunctivus from Adolfo López Mateos El Infiernillo Reservoir, Michoacán-Guerrero, Mexico, Rev. Mex. Biodivers., 2013, vol. 84, p. 318.

Schaefer, S.A., Homology and evolution of the opercular series in the loricarioid catfishes (Pisces: Siluroidei), J. Zool., 1988, vol. 214, p. 81.

Schaefer, S.A. and Lauder, G.V., Historical transformation of functional design: evolutionary morphology of feeding mechanisms in loricarioid catfishes, Syst. Biol., 1986, vol. 35 , p. 489 .

Schaefer, S.A. and Lauder, G.V., Testing hypotheses of morphological change: biomechanical decoupling in loricarioid catfishes, Evolution, 1996, vol. 50, p. 1661.

Serov, D., Harnischwelse in Suü dostasien, DATZ, 2004, vol. 2, p. 18.

Stolbunov, I.A. and Gusakov, V.A., Diet and growth characteristics of the Nile tilapia Oreochromis niloticus (L., 1758) in native conditions: lakes of Vietnam, Rybn. Khoz., 2015, no. 6, p. 91.

Stolbunov, I.A. and Tran Duc Dien, Mass alien fish species in the fish fauna of inland waters in Central Vietnam, Inland Water Biol., 2019, vol. 12, no. 4, p. 478. https://doi.org/10.1134/S1995082919040163

Stolbunov, I.A., Gusakov, V.A., Chan Duc Zien, and Nguyen Thi Hai Thanh, Report on the theme ECOLAN-3.2 "Taxonomic Diversity, Ecology, and Behavior of Freshwater Aquatic Organisms," Section "Species Diversity and Biology of Fish in Continental and Island Water Bodies of Different 
Types, ” Nha Trang: Ross.-V'etnam. Trop. Nauchno-Issled. Tekhnol. Tsentr, Primorsk. Otd., 2015.

Stolbunov, I.A., Gusakov, V.A., Chan Duc Zien, and Nguyen Thi Hai Thanh, Report on the theme ECOLAN-3.2 "Taxonomic Diversity, Ecology, and Behavior of Freshwater Aquatic Organisms," Section "Species Diversity and Biology of Fish in Continental and Island Water Bodies of Different Types, ” Nha Trang: Ross.-V'etnam. Trop. Nauchno-Issled. Tekhnol. Tsentr, Primorsk. Otd., 2017a.

Stolbunov, I.A., Gusakov, V.A., Tran Duc Dien, and Nguen Thi Hai Than, Distribution, systematics, morphology and feeding of suckermouth armored catfishes (Siluriformes: Loricariidae) in Vietnam, in V Int. Symp. "Invasion of Alien Species in Holarctic,"Yaroslavl: Filigran, 2017b, p. 124.

Stolbunov, I.A., Tran Duc Dien, and Armbruster, J.W., Suckermouth-armored catfish (Siluriformes: Loricariidae) of central and southern Vietnam, Inland Water Biol., 2020, vol. 13 , no. 4 , p. 627.

https://doi.org/10.1134/S1995082920040100
Stolbunov, I.A., Tran Duc Dien, and Karabanov, D.P., Taxonomic composition and distribution of alien armored catfishes (Siluriformes: Loricariidae) in south Vietnam, Inland Water Biol., 2021, vol. 14, no. 3, p. 263. https://doi.org/10.1134/S1995082921030123

Weber, C., Révision du genre Pterygoplichthys sensu lato (Pisces, Siluriformes, Loricariidae), Rev. Franc. Aquariol. Herpetol., 1992, vol. 19, p. 1.

Welcomme, R.L. and Vidthayanom, C., The Impacts of Introductions and Stocking of Exotic Species in the Mekong Basin and Policies for Their Control, MRC Technical Paper no. 9, Phnom Penh: Mekong River Commission, 2003.

Zworykin, D.D. and Budaev, S.V., Non-indigenous armoured catfish in Vietnam: invasion and systematics, Ichthyol. Res., 2013, vol. 60, p. 327.

Translated by N. Ruban 